and manuscript materials relating primarily to Canada, British Columbia, and the Pacific Northwest.

\section{Deaths}

Charles Marshall Adams, librarian emeritus at the University of North Carolina at Greensboro (UNC-G), and past-president of ACRL (1950-1951), died December 8, 1991, at the age of 83 . Adams received his bachelor's degree from Amherst College in 1929 and went on to obtain his master's degrees in English and library science from Columbia University. From 1934 to 1938 he worked at the New York Public Library, then was assistant to the director and librarian in charge of special collections at Columbia University from 1938 to 1945. In 1945 he became director of the library at UNC-G, resigning in 1969 to become director of the Sinclair Library at the University of Hawaii, where he served until his retirement in 1973. In 1978 he was awarded an honorary doctorate in humane letters by UNC-G

The author of many professional articles and reviews, Adams was also a distinguished bookman. His collection of the works of Randall Jarrell and writers of the Southern Appalachians were given to the Amherst College Library.

May Dornin, former university archivist at the University of California, Berkeley, died on February 19 at the age of 94 . Dornin received her master's in history at UC-Berkeley in 1922, six years after joining the library as a student assistant in the Catalog Department. She later became senior assistant in the department, then was appointed university archivist in 1949 and held that position until her retirement in 1964. After retiring, Dornin co-authored A Pictorial History of the University of California and assumed responsibility for many articles in The Centennial Record, both published in 1968.

Abbot Fidelis James Dunlap, former librarian and library director at Saint Leo College (SLC) in Florida, died March 25 at the age of 66. Dunlap earned his MLS in 1957 from Catholic University of America. After serving as library director at SLC, he was appointed executive vice-president of the college, was a member of the Board of Trustees, and became

fourth Abbot of Saint Leo Abbey from 1970 to 1985.

Margie May Helm, former head librarian at Western Kentucky University (WKU), died on December 19, 1991, at the age of 97 . Helm began her career at WKU in 1920, then became head librarian in 1923 and held that position until her retirement in 1965. Active in the profession, she served as president of the Kentucky Library Association in 1929, was one of the founders of the Bowling Green Public Library, and was a member of the State Board for the Certification of Librarians from 1938 to 1955. She also contributed scholarly articles to Library Quarterly, Library Joumal, and the Kentucky School Joumal. Proud of her profession, Helm once said, "I believe in reading as a form of education and of elimination of racial and other prejudices. Knowledge of other peoples and other ways of life will contribute to a better understanding between peoples. I'm proud to be a librarian."

Luella (Becky) Pollock, former college librarian at Reed College, Portland, Oregon, died March 17. Pollock directed the Reed Library from 1957 until her retirement in 1987. She also held positions at the University of Iowa (19421945) and Vassar College (1945-1957). She planned and directed a 1962 addition to the Reed Library and was responsible for much of the planning for the 1989 addition. The library room that houses a browsing collection of new books and recent newspapers and periodicals is named in her honor.

\title{
Advertiser index
}

$\begin{array}{ll}\text { American Library Assn. } & 324 \\ \text { American Psychological } & \text { cover 2 } \\ \text { AMIGOS } & 308 \\ \text { Ballen } & 319 \\ \text { Blackwell } & 312 \\ \text { Cambridge Scientific } & 305 \\ \text { EBSCO } & \text { cover 4 } \\ \text { Gaylord } & 336 \\ \text { Haworth } & 316 \\ \text { K.G. Saur } & \text { cover } 3 \\ \text { Sociological Abstracts } & 327 \\ \text { H.W. Wilson } & 325\end{array}$

